\begin{tabular}{|l|l|l|l|l|l|}
\hline J. Tek. Ling. & Vol. 10 & No. 1 & Hal. 54 - 61 & Jakarta, Januari 2009 & ISSN 1441-318X \\
\hline
\end{tabular}

\title{
PEMETAAN GEOHIDROLOGI DAERAH DONOROJO KABUPATEN PACITAN
}

\author{
Teguh Prayogo \\ Peneliti di Pusat Teknologi Sumberdaya Mineral \\ Badan Pengkajian dan Penerapan Teknologi
}

\begin{abstract}
Water is a component in the earth that is very important for human life. The availability of water is always wanted to meet a demand of water supply, such as for drinking water, washing, taking a bath, and etc. Along with population growth, so the need of water will be still increasing, including Tanah Datar. In this paper will be described concerning to characteristics, and condition of water in Pacitan Area, East Java Province, especially Donorojo district. This location occupies geographically between the latitude of $00^{\circ} 17^{\prime}$ and $00^{\circ} 39^{\prime}$ south and the longitude of $100^{\circ} 19^{\prime}$ and $100^{\circ} 51^{\prime}$ 'east Based on survey in field, condition of aquifer in Telaga Banta is located in $20-60$ meter depth, and the result of laboratory points to that the quality of water in this area meets the requirement for drinking water.

The main uses of ground water include irrigation uses, drinking-water and other public uses, and for supplying domestic water to people who do not receive publicsupply water. The majority of water used for self-supplied domestic and livestock purposes came from ground-water sources.
\end{abstract}

Keywords : water, characteristic, exploration

\section{PENDAHULUAN}

\subsection{Latar Belakang}

Air adalah zat yang penting bagi semua bentuk kehidupan yang dimuka bumi. Di banyak tempat di dunia terjadi kekurangan persediaan air. Pengaturan air yang kurang baik dapat menyebakan kekurangan air, monopolisasi serta privatisasi dan bahkan mungkin bias menyulut konflik. Demikian pula di Indonesia, dimana saat ini air merupakan permasalahan yang kronik dan pelik, mulai dari peristiwa banjir sampai kekeringan.

Wilayah Indonesia, menurut LIPI, memiliki $6 \%$ dari persediaan air dunia atau sekitar 21\% persediaan air Asia Pasifik' ${ }^{11}$. Namun demikian, kelangkaan dan kesulitan mendapatkan air bersih dan layak pakai di banyak tempat dan semakin mendesak dari tahun ke tahun. Kecenderungan konsumsi air naik secara eksponensial, sedangkan ketersediaan air bersih cenderung melambat akibat kerusakan alam dan pencemaran.

Air bersih sering menjadi problem utama di daerah-daerah di seluruh Indonesia. Problema ini muncul karena kondisi geologi daerah tersebut, misalnya daerah kars, batuan beku, dan lain. Kebutuhan air bersih seringkali tidak bisa hanya dengan mengandalkan air permukaan, karena pada daerah tertentu air permukaan tersedia dalam jumlah yang terbatas. 
Oleh karena itu perlu adanya usahausaha yang bisa membantu memecahkan permasalahan yang timbul, salah satunya adalah memetakan sumberdaya air tanah di daerah Donorojo, Kabupaten Pacitan.

Diharapkan dengan adanya kegiatan ini tergambarkan potensi sumberdaya air di daerah tersebut dan permasalahan yang muncul, sehingga membantu dalam penanganannya.

\subsection{Tujuan}

Tujuan dari penelitian ini adalah (1) mengidentifikasi sumberdaya air di daerah Pacitan bagian barat, (2) dan memetakan kondisi sumberdaya air daerah penelitian.

\section{METODOLOGI}

\subsection{Metodologi dan Peragaan}

Metodologi dalam penelitian ini secara garis besar terdiri dari studi pendahuluan, survei geohidrologi, dan pembuatan peta.

\section{1). Studi Pendahuluan}

Studi pendahuluan ini dilaksanakan dengan melakukan kegiatan tinjauan pustaka, menginventarisasi data dan informasi, mempersiapkan peta dasar kerja, dan penentuan rencana survei.

\section{2). Survei Geohidrologi}

Survei geohidrologi yang dilakukan pada peneliitian ini berupa pengamatan lokasilolokasi keberadaan mata air atau sumber air (luweng).

\section{3). Pembuatan Peta}

Pekerjaan pembuatan peta ini dilakukan untuk memberikan gambaran tentang penyebaran sumber air dan kondisi aquifer didaerah penelitian dengan mengeplotkan lokasi sumber mata air.

\subsection{Geologi daerah penelitian}

Daerah survei merupakan lajur Pegunungan Selatan Jawa Timur. Morfologinya sebagian besar didominasi oleh satuan morfologi kars dan sebagian kecil satuan dataran aluvial ${ }^{5}$.

Satuan geomorfologi kars mencakup hampir $98 \%$ daerah penyelidikan dicirikan oleh hamparan berbentuk plateau batugamping yang mempunyai topografi kars. Gejala kars ini ditunjukkan oleh adanya gua batugamping, aliran sungai bawah tanah, dolina dan ovala. Bukit-bukit kecil menjulang antara 20-50 meter di atas muka laut merupakan bentukan hasil erosi, yang umumnya disusun oleh batugamping terumbu. Bentuk bukitnya seperti kerucut, kerucut terpancung, meja, tabung dan sebagainya yang dipengaruhi oleh ragam batugamping penyusunnya. Wilayah perbukitan ini dikenal sebagai Pegunungan Sewu. Sungai besar yang memotong satuan ini adalah Sungai Baksoka dan Sungai Barong yang kelurusaanya dipengaruhi oleh struktur rekahan dan retakan.

Satuan dataran aluvial yang disusun oleh batuan aluvial sebarannya sangat terbatas, yaitu di sepanjang aliran sungai besar.

\subsection{Peralatan yang digunakan}

Peralatan yang dibutuhkan pada penelitian ini terdiri dari Global Positioning System (GPS), kompas geologi, meteran, digital camera, dan perangkat lunak SIG.

\section{HASIL DAN PEMBAHASAN}

Hasil studi pendahuluan dan survei lapangan (survei geohidrologi) didaerah Donorojo, Kabupaten Pacitan menunjukkan bahwa salah satu permasalahan yang menonjol di Kabupaten Pacitan adalah sulitnya mendapatkan air tanah. 
Berdasarkan survei lapangan di daerah Donorojo, yang dijadikan sebagai fokus penelitian, dijumpai mata air air atau luweng yang tersebar dibeberapa tempat atau lokasi, yaitu di daerah Sekar, Sukodono, Gendaran, Klepu, Gedompol, Widoro, Sendang, dan Kalak seperti terlihat pada :

Tabel 1. Mata Air atau Luweng di Daerah Donorojo

\begin{tabular}{|l|l|l|}
\hline Ilo & \multicolumn{1}{|c|}{ Luweng } & \multicolumn{1}{c|}{ Lokasi } \\
\hline 1 & Tanjung & Sekar \\
\hline 2 & Pagihan & Sekar \\
\hline 3 & Sumur produksi PDAM & Sekar \\
\hline 4 & Kaligede & Sekar \\
\hline 5 & Sumur Gali & Sekar \\
\hline 6 & Dung Banteng & Sekar \\
\hline 7 & Air Ketiban & Sukadana \\
\hline 8 & Turiredjo & Gendaran \\
\hline 9 & Klepukrajan & Klepu \\
\hline 10 & Ngorodowo & Gedompol \\
\hline 11 & Dungtimo & Widoro \\
\hline 12 & Sendang & Sendang \\
\hline 13 & Besuci & Kalak \\
\hline 14 & Wiran & Kalak \\
\hline 15 & Kobong & Kalak \\
\hline & & \\
\hline
\end{tabular}

Hasil pengamatan dilapangan memberikan gambaran bahwa keberadaan dari luweng atau mata air di daerah penelitian terdapat pada lokasi yang terpisah-pisah dan terpencar-pencar, dimana debit air yang ada tidaklah begitu besar. Kemungkinan besar antara luweng yang satu dengan luweng yang lainnya tidak terkait atau bukan suatu satu kesatuan luweng yang menyatu, akan tetapi merupakan luweng-luweng yang menyendiri atau isolir.

Kondisi dari masing-masing luweng cukup berbeda, dimana ada luweng yang dijadikan sebagai sumber utama pengambilan air bagi penduduk sekitarnya karena volume airnya relatif stabil. Akan tetapi banyak dijumpai luweng yang mengalami penyusutan volume yang cukup signifikan.

Secara umum di daerah penelitian (Donorojo) yang dominasi litologinya adalah batugamping, masyarakatnya tidak mempunyai sumur gali untuk memenuhi keberadaan masyarakat berharap terhadap keberadaan luweng-luweng didaerah penelitian. Ironinya, lokasi sumber air tersebut berada jauh dari perumahan penduduk dan kadang berada daerah daerah cekungan yang beda tingginya mencapai 75 meter terhadap pemukiman penduduk.

Kondisi ini mendorong aparat dan masyarakat sekitar melakukan program pipanisasi dari sumber air atau luweng ke bak penampungan air sementara dan dilanjutkan pipanisasi ke bak penampungan utama yang dekat dengan perumahan penduduk.

Berdasarkan tinjauan dan analisis aspek geologi, fenomena diatas tidaklah mengherankan karena sebagian besar wilayah Kabupaten Pacitan tertutup oleh (covered by) batugamping. Dengan demikian keberadaan air tanah umumnya diandalkan dari rekahan batugamping atau bahkan rongga-rongga batugamping tersebut.

Demikian halnya dengan Kabupaten Pacitan pada bagian barat, termasuk di daerah Donorojo yang merupakan daerah yang umumnya terdiri dari batugamping. Akibatnya, daerah ini sering mengalami kesulitan air bersih. Di daerah batugamping, air tanah tersimpan dalam suatu konduit yang berupa rekahan batugamping, rongga - rongga batugamping atau sungai bawah tanah. 


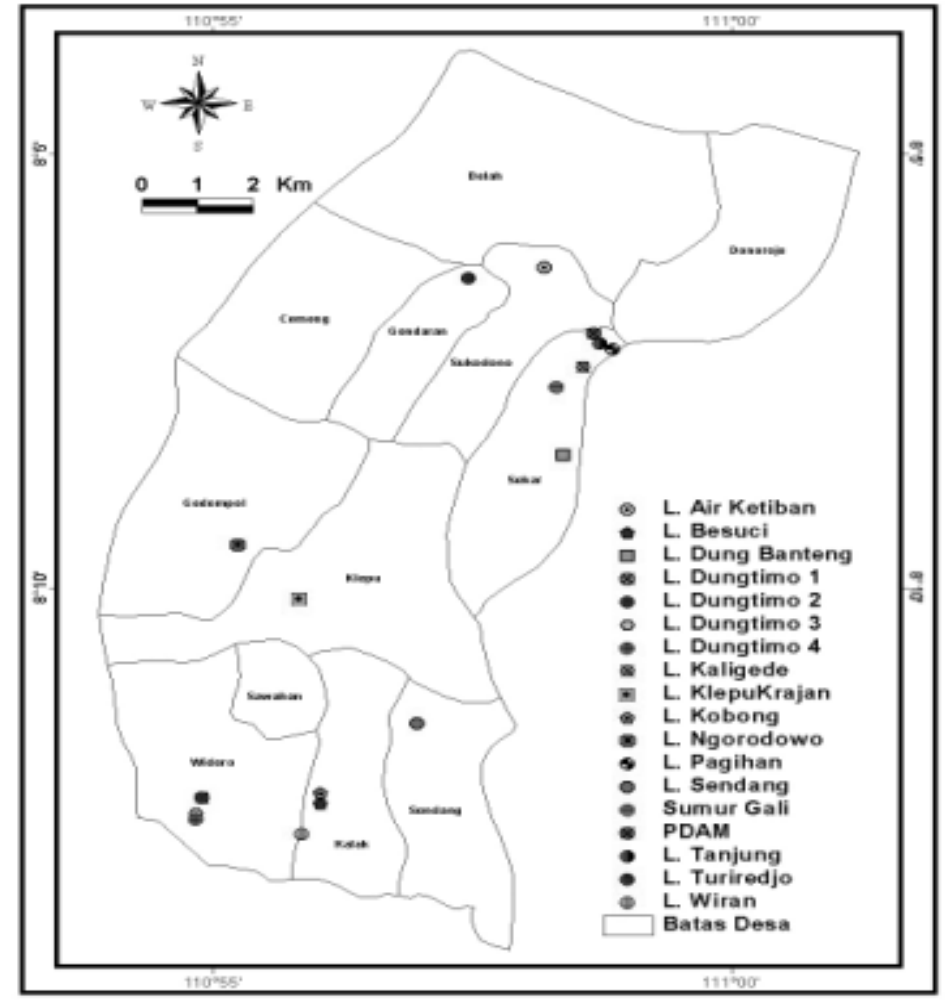

Gambar 1. Peta sebaran Luweng di daerah Penelitian

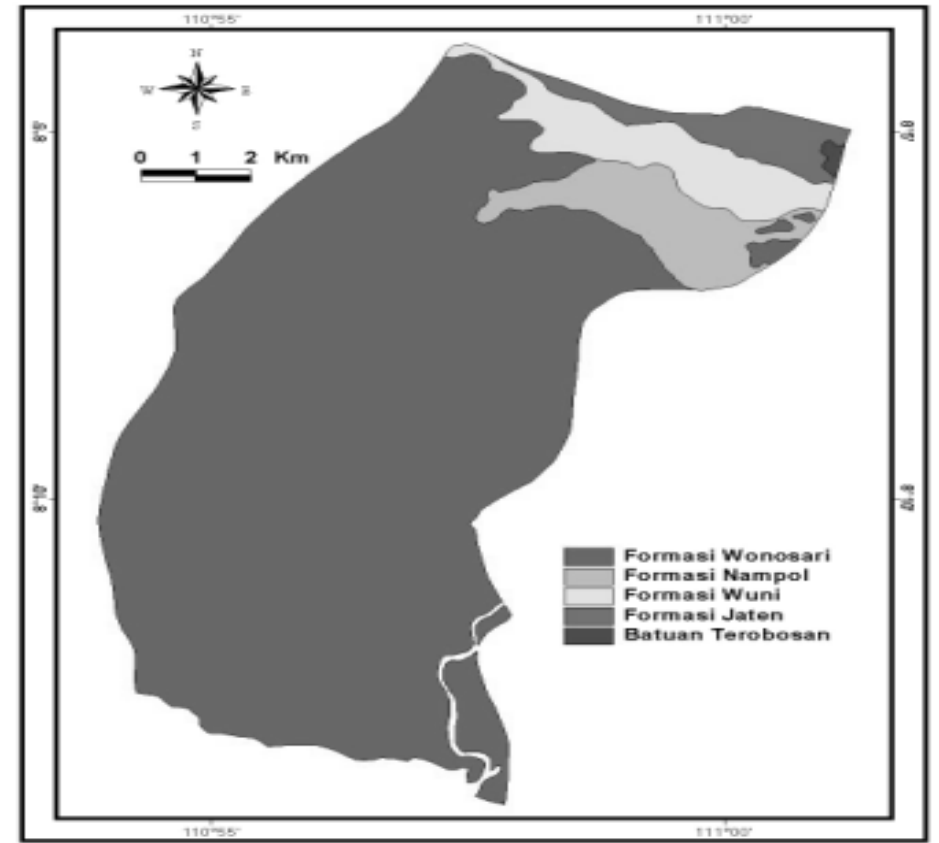

Gambar 2. Peta Geologi Daerah Donorojo 5)

Pemetaan Geohidrologi Daerah... J.Tek.Ling. 10 (1): 54 - 61 
Pada Gambar 2 diatas terlihat bahwa daerah Donorojo, Kabupaten Pacitan didominasi oleh formasi Wonosari (warna hitam atau di aarsir lain biru) yang menempati sekitar $75 \%$ dari daerah penelitian, terhadap dari bagian utara ke bagian selatan. Formasi Wonosari ini merupakan formasi geologi yang didominasi oleh batugamping, dimana jenis batuannya terdiri dari batugamping terumbu, batugamping berlapis, batugamping mengeping, batugamping pasiran dan napal, tebal keseluruhan kurang lebih 160 meter. Formasi Wonosari ini menindih selaras Formasi Nampol dan menjemari dengan Formasi Oyo, berumur Miosen Tengah hingga Miosen Akhir dan terbentuk di lingkungan laut dangkal ${ }^{1}$.
Tinjauan geomorfologi juga menguatkan adanya dominasi keberadaan batugamping pada daerah penelitian yang dapat dilihat dari peta topografi Gambar 3. Hal ini terlihat banyak bukit-bukit kecil yang ditandai dengan kenampakan kontur yang bulatbulat kecil yang menjulang antara $20-60$ meter, dimana kontur-kontur bulat tersebut kadang-kadang menyatu dan kadangkadang terpisah. Gejala kars ini merupakan bentukan hasil erosi, yang umumnya disusun oleh batugamping terumbu. Bentuk bukitnya seperti kerucut, kerucut terpancung, meja, tabung dan sebagainya yang dipengaruhi oleh ragam batugamping penyusunnya.

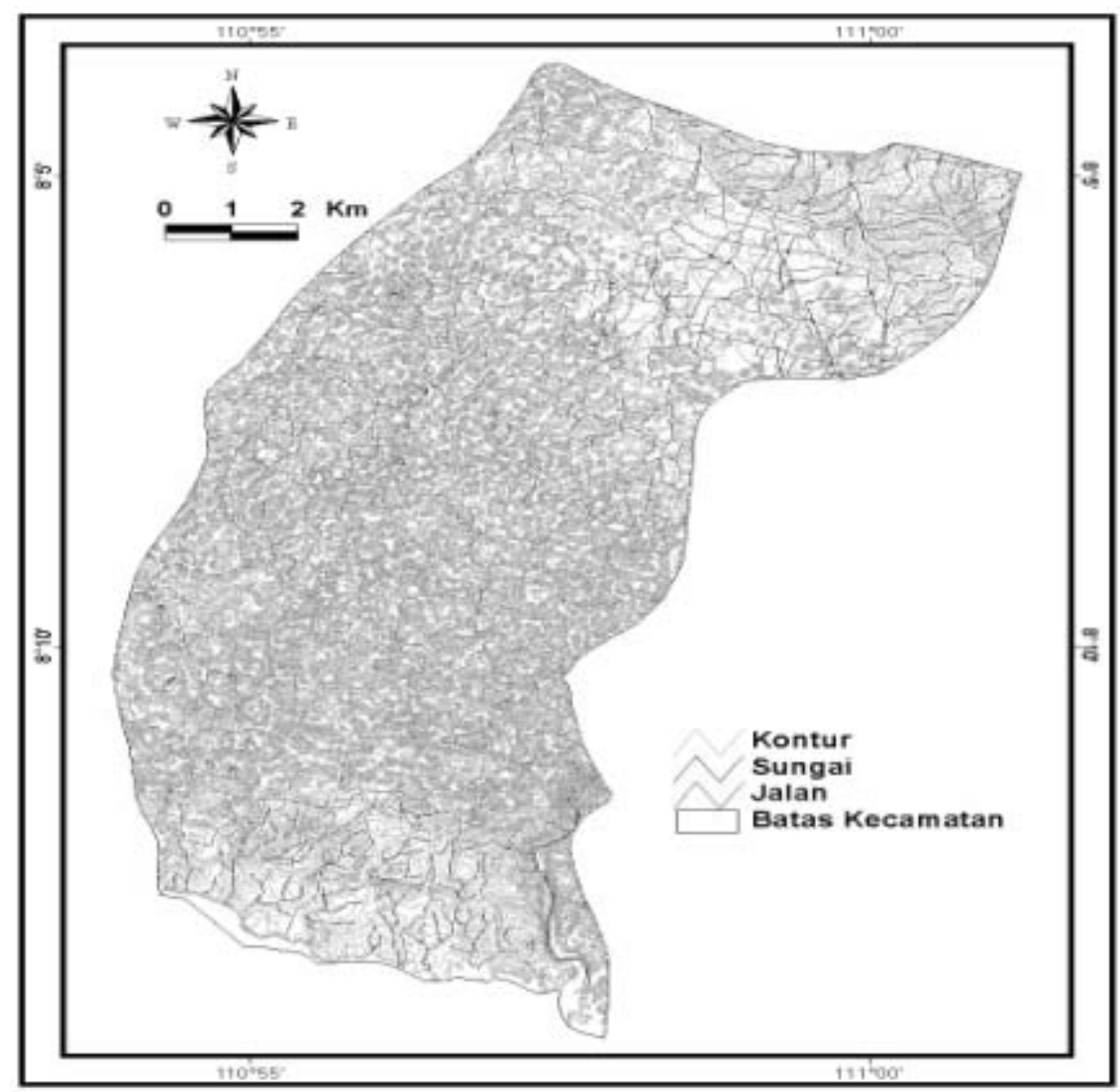

Gambar 3. Peta Topografi Daerah Donorojo 
Sementara itu, berdasarkan tinjauan geohidrologi, maka secara umum air tanah pada daerah penelitian merupakan aquifer dengan aliran melalui celah, rekahan atau saluran, dimana jenis aquifernya terbagi menjadi 2 bagian, yaitu aquifer dengan produktifitas sedang, dan aquifer pada daerah dengan airtanah langka. Aquifer produktifitas sedang ini menempati sebagian besar daerah penelitian sekitar $75 \%$ dan melampar dari bagian utara ke bagian selatan. Litologi yang mendasari aquifer tipe ini adalah batugamping berlapis dan batugamping terumbu. Sedangkan aquifer pada daerah dengan airtanah langka menempati segian kecil dari daerah penelitian yaitu dibawah $25 \%$. Aquifer tipe ini hanya menempati pada bagian utara dengan litologi yang mendasarinya adalah endapan vulkanik dan endapan marin seperti terlihat pada Gambar 4.

Keterkaitan antara keberadaan dari luweng atau sumber air didaerah penelitian berdasarkan keterdapatannya dilapangan dengan aspek geologi, aspek geomorfologi dan geohidrologi, maka dapat dijelaskan sebagai berikut :

Singkapan-singkapan atau pemunculan sumber air yang setempat-setempat atau terpisah di daerah Donorojo terkait erat dengan fenomena kondisi geologi didaerah tersebut, dimana luweng-luweng tersebut hanya dapat dijumpai pada daerah yang tersusun dari litologi batugamping (lihat Gambar 1 dan Gambar 2).

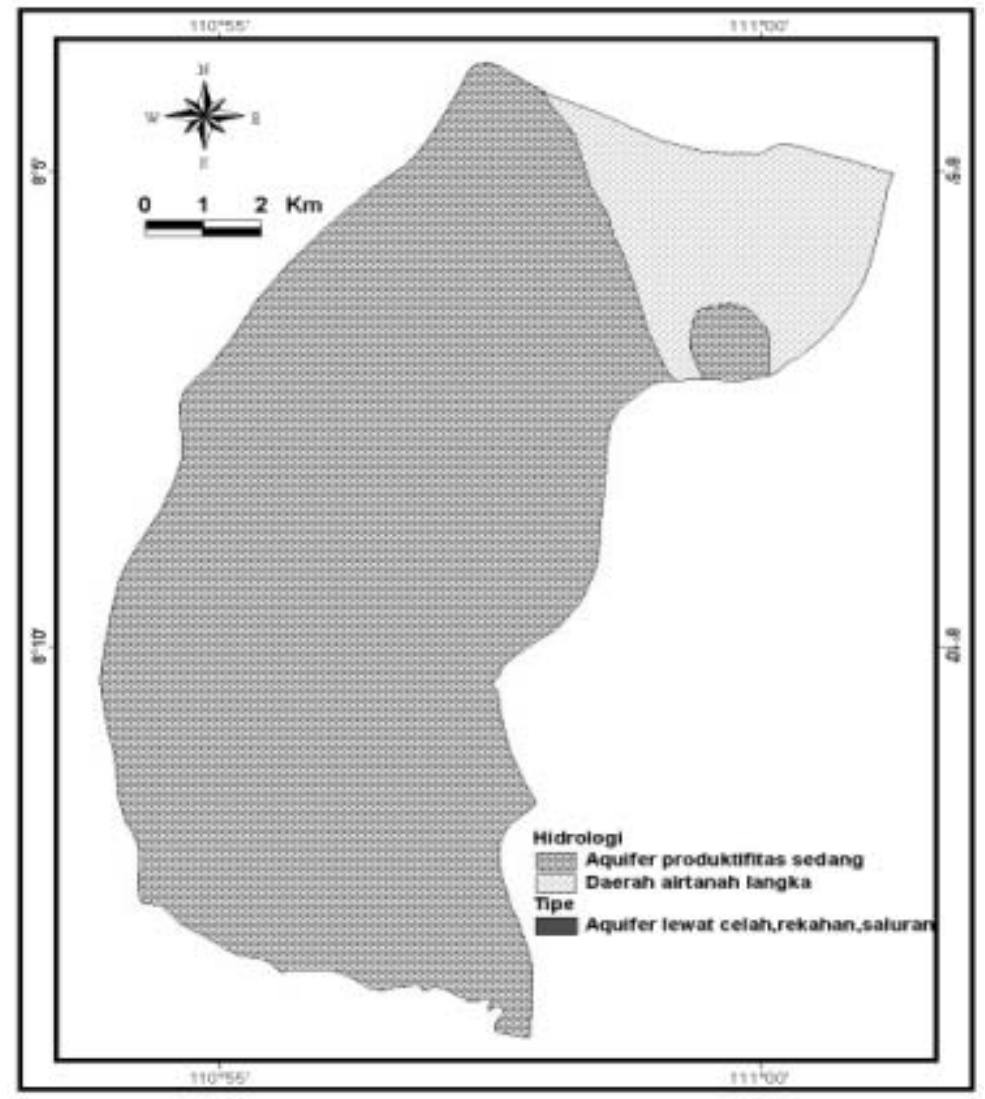

Gambar 4. Peta Geohidrologi Daerah Donorojo ${ }^{2}$ 
Komposisi atau penyusun litologi batugamping yang beragam, kekerasan pada tiap bagian yang berbeda-beda dan juga ditunjang dengan adanya rekahanrekahan yang berkembang pada daerah tersebut, menyebabkan proses pelapukan dan pelarutan oleh media air pada liotlogi itu juga memberikan efek yang bervariasi. Sementara itu media air mencari bagianbagian yang lunak, adanya zona rekahan, dan kompoisi yang relatif seragam guna melakukan proses infiltrasi dan pelarutan, sehingga terbentuk lembah atau cekungan dan bahkan aliran air bawah tanah atau sungai bawah tanah pada daerah batugamping. Daerah-daerah inilah yang bisa sebagai sarana atau tempat berkumpulnya air, baik itu yang berasal dari air hujan atau lainnya. Sering kali aliran-aliran air didaerah batugamping muncul pada daerah atau bagian lain sebagai mata air atau luweng.

Sedangkan bagian-bagian yang keras akan tersisakan sebagai gundukangundukan atau bukit-bukit kecil yang beragam. Ketinggian atau perbedaan elevasi dengan daerah sekitarnya dipengaruhi oleh seberapa besar perbedaan kekerasan dan komposisinya karena pengaruh intensitas pelarutan dan pelapukan. Fenomena diatas seperti ditunjukkan pada Gambar 3 yang terwakili dalam kontur membulat yang kecil dalam jumlah banyak sebagai ciri dari topografi karst. Hal ini menunjukkan bahwa faktor geologi berperan dalam mempengaruhi pembentukan fenomena diatas.

Berdasarkan Gambar 1 dan Gambar 4 terlihat bahwa berdasarkan tipe alirannya, sumberdaya air atau aquifer yang berkembang pada daerah penelitian adalah air tanah atau aquifer dengan aliran melalui celah, rekahan atau saluran yang terbentuk pada litologi batugamping karena pengaruh proses pelarutan. Sementara itu, berdasarkan tingkat produktifitasnya, maka air tanah yang terbentuk pada daerah penelitian adalah aquifer dengan produktifitas sedang.

Kenampakan-kenampakan pada gambar diatas merupakan fenomenafenomena alam dimana faktor geologi memainkan peran yang vital.

\section{KESIMPULAN}

Berdasarkan hasil survey lapangan dan analisis geologi, geomorlogi, dan geohidrologi, maka secara garis besar dapat disimpulkan sebagai berikut :

- Daerah penelitian sering mengalami kesulitan air karena dominiasi litologi batugamping.

- Sumberdaya air yang berkembang di daerah penelitian merupakan aquifer dengan aliran melalui celah, rekahan atau saluran dengan tingkat produktifitas sedang.

- Faktor geologi berperan penting dalam pembentukan fenomena di daerah penelitian.

- Perlu dilakukan pengelolaan sumberdaya air secara integratif dan efisien guna memanfaatkan potensi yang ada secara optimal

\section{DAFTAR PUSTAKA}

1. Danaryanto dkk, 2005; "Air Tanah di Indonesia dan Pengelolaannya", Direktorat Tata Lingkungan Geologi dan Kawasan Pertambangan, Direktorat Jendral Geologi dan Sumberdaya Mineral, Departemen Energi dan Sumberdaya Mineral.

2. Djaeni A., 1982, "Peta Hidrogeologi Indonesia Lembar Yogyakarta (IX) Skala 1 : 250.000", Direktorat Geologi Tata Lingkungan. 
3. 2003, "Kabupaten Pacitan Dalam Angka 2003”, Badan Pusat Statistik Kabupaten Pacitan, Badan Perencanaan Pembangunan Daerah.

$4 . \quad$ _____ http://www.walhi.or.id/ kampanye/air/air_info/

5. Samodra H., Gafoer S., Tjokrosapoetro S., 1992, "Peta Geologi Lembar Pacitan, Jawa Skala 1 : 100.000", Pusat Penelitian dan Pengembangan Geologi, Direktorat Jendral Geologi dan Sumberdaya Mineral, Departemen Pertambangan dan Energi. 